\title{
Karakteristik Interaksi Fluida-Batuan dan Pendugaan Suhu Reservoir Pada Sistem Panasbumi Kamojang Garut Berdasar Data Kimia Gas Sumur Produksi
}

\author{
Yoga Aribowo ${ }^{1 *}$, Marcelina Ramadhani ${ }^{1}$ \\ ${ }^{1}$ Departemen Teknik Geologi, Universitas Diponegoro, Semarang
}

\begin{abstract}
Abstrak
Lapangan Panasbumi Kamojang merupakan salah satu lapangan tertua yang berproduksi di Indonesia, dengan karakter dominasi uap. Salah satu cara memahami tatanan sistem panasbumi adalah dengan menganalisis kimia fluida, baik air maupun gas. Analisis geokimia gas pada lapangan Kamojang ini dilakukan pada gas yang berasal dari 10 sumur produksi, dengan metode kromatografi gas untuk gas non reaktif dan metode titrasi untuk gas reaktif. Hasil analisis diplot pada beberapa diagram segitiga untuk analisis asal air. Perhitungan suhu reservoir dilakukan dengan geotermometer berdasar formula dari beberapa penulis sebelumnya. Berdasar diagram segitiga N2-He-Ar, fluida pada sumur B, E, A, G diperkirakan berasal dari gas magmatik, sedangkan sumur I, H, D, C dari air meteorik, dan berdasar diagram segitiga N2-CO2-Ar, input gas diperkirakan berasal dari gas magmatik. Berdasar perhitungan geotermometer, suhu reservoir berkisar antara $230-279,7^{\circ} \mathrm{C}$.
\end{abstract}

Kata kunci: Lapangan Panasbumi Kamojang, geokimia gas, asal fluida, geotermometer

\begin{abstract}
Kamojang field is one of the oldest produced geothermal field in Indonesia. It well known as vapor dominated geothermal system.Geochemical analysis and interpretation of discharged gas could be a guide to comprehend the fluid-rocks interaction pattern, the source of fluids, and the temperature of reservoir. Methods used in this research are gas chromatography for non reactive gas and titration for reactive gas, followed by ternary diagram plotting and geothermometry calculation. Based on ternary N2-He-Ar, fluids of Well- B, E, A, G interpreted as magmatic source fluids, while fluids from Well $I, H, D$, and C more likely meteoric influenced fluids. Based on N2-CO2-Ar, most gases are magmatic source. The geothermometry calculation resulted in reservoir temperature predicted range of $230-279,7^{\circ} \mathrm{C}$.
\end{abstract}

Keywords: Kamojang Geothermal Field, gas geochemistry, fluids genetics, geothermometry

\section{PENDAHULUAN}

Lapangan Panasbumi Kamojang merupakan lapangan panasbumi tertua yang beroperasi di Indonesia, di mana pengeboran dilakukan pertama kali pada 1975. Sistem Panasbumi Kamojang merupakan sistem dominan uap, sehingga karakteristik sistemnya cukup menarik untuk dikaji, terutama terkait pola interaksi fluida hidrotermal dengan batuan di bawah permukaan (geoindikator), dan juga aplikasi metode geotermometer gas untuk pendugaan temperatur reservoirnya. Analisis geokimia gas banyak diaplikasikan di lapangan panasbumi karena konsentrasi gas indeks tertentu yang muncul ke permukaan mencerminkan proses fisikokimia dan geologi yang terjadi di bawah permukaan yang melibatkan fluida hidrotermal dengan batuan pada sistem, sehingga dapat membantu memprediksi dinamika dan kondisi geologi bawah permukaan pada sistem. Daerah dengan tatanan geologi vulkanik medan terjal, biasanya air reservoir (klorida) tidak muncul ke permukaan sebagai manifestasi, sehingga untuk interpretasi kondisi dan dinamika reservoir yang digunakan adalah analisis kimia gas (Nicholson, 1993). Tujuan dari penelitian ini adalah mendapatkan gambaran jenis dan variasi fluida yang berpengaruh pada sistem, dan mengetahui dinamika kondisi fisikokimia di bawah permukaan, terutama pendugaan suhu reservoir dari penelitian ini berdasar analisis kimia sampel gas baik dari sumur produksi maupun dari manifestasi permukaan, dengan spektrometri massa dan menginterpretasi hasilnya dengan menggunakan beberapa crossplot dan juga formula perhitungan.

*) Korespondensi: yogaribowo@gmail.com 


\section{Gas Panasbumi}

Gas indikator yang selalu hadir pada area manifestasi panasbumi adalah $\mathrm{CO}_{2}, \mathrm{H}_{2} \mathrm{~S}, \mathrm{NH}_{3}$, $\mathrm{N} 2, \mathrm{H}_{2}$ dan $\mathrm{CH}_{4}$, gas-gas ini sering disebut "gas yang tidak dapat terkondensasi"(Noncondensible gases/NCG) (Nicholson, 1993). Uap panasbumi terbentuk oleh proses mendidihnya fluida di bawah permukaan. Fase uap yang terbentuk kemudian bermigrasi ke permukaan secara relatif vertikal, sedangkan air residu selalu bermigrasi secara lateral dari zona pendidihan. Jika air kemudian mucul di permukaan, biasanya jarak antara titik luaran ini (zona outflow) dengan zona upflow umumnya beberapa kilometer. Gas yang paling melimpah dalam sistem panas bumi adalah $\mathrm{CO}_{2}$ yang dihasilkan oleh beberapa proses, antara lain reaksi mineral dan batuan, degradasi organik dalam batuan sedimen, reaksi dekat permukaan, pendidihan air meteorik dan beberapa mungkin berasal dari magmatik. Gas $\mathrm{CO}_{2}$ adalah gas yang penting dalam sistem panas bumi untuk mengetahui pengaruh kimia air seperti $\mathrm{pH}$, densitas, hubungan titik didih, deposisi mineral sekunder dan kedalaman titik didih. Gas-gas umum lainnya yang digunakan untuk mengetahui sumber sistem panas bumi adalah hidrogen sulfida, metan, argon, helium dan nitrogen.

\section{METODOLOGI}

Pengambilan sampel gas dilakukan dengan menggunakan botol vakum berisi larutan $\mathrm{NaOH} 4 \mathrm{~N}$ yang dipersiapkan di laboratorium dengan cara mengalirkan $100 \mathrm{ml}$ larutan $\mathrm{NaOH}$ bebas $\mathrm{CO}_{2}$ ke dalam botol kedap udara yang terlebih dahulu divakumkan agar tidak terjadi kontaminasi udara. Dengan menggunakan karet silikon, botol sampel dihubungkan dengan corong penangkap gas yang diletakkan di atas manifestasi tepat pada keluarnya bubble gas (Gambar 1).

\section{Analisis Laboratorium}

Analisis sampel gas dilakukan di Laboratorium Isotop dan Kimia, Pusat Aplikasi Teknologi Isotop dan Radiasi, BATAN, Jakarta. Analisis gas dengan dua metode, yaitu metode kromatografi gas untuk gas non reaktif $\left(\mathrm{H}_{2}\right.$, $\mathrm{He}, \mathrm{Ar}, \mathrm{N}_{2}$, dan $\mathrm{CH}_{4}$ ) dan metode titrasi untuk gas reaktif $\left(\mathrm{CO}_{2}\right.$ dan $\left.\mathrm{H}_{2} \mathrm{~S}\right)$.

Analisis gas non reaktif yaitu $\mathrm{H}_{2}, \mathrm{He}, \mathrm{Ar}, \mathrm{N}_{2}$, dan $\mathrm{CH}_{4}$ dilakukan dengan menggunakan alat kromatografi gas Argilent Technologies 7890

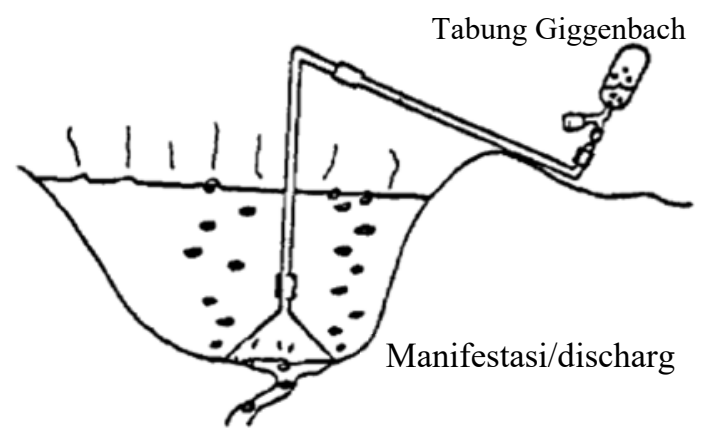

Gambar 1. Skema pengambilan sampel gas

A yang dilengkapi dengan system injeksi model Arnell.

Pada analisis $\mathrm{H}_{2}$ dan $\mathrm{He}$ digunakan gas $\mathrm{Ar}$ sebagai gas pembawa, sedangkan $\mathrm{N}_{2}$, Ar, dan $\mathrm{CH}_{4}$ digunakan gas $\mathrm{He}$ sebagai gas pembawa. Kedua analisis gas tersebut dilakukan secara simultan menggunakan dua detektor thermal conductivity (TCD). Sistem alat kromatografi gas Argilent Technologies beroperasi secara simultan untuk analisis gas $\mathrm{H}_{2}, \mathrm{He}, \mathrm{N}_{2}$, Ar, dan $\mathrm{CH}_{4}$ dengan menggunakan software Ezchrom. Untuk analisis gas reaktif yang terlarut dalam $\mathrm{NaOH}$, yaitu $\mathrm{CO}_{2}$ dan $\mathrm{H}_{2} \mathrm{~S}$ digunakan metode titrasi (Giggenbach dan Goguel, 1989). Gas $\mathrm{CO}_{2}$ dititrasi menggunakan larutan $\mathrm{HCl}$, sedangkan $\mathrm{H}_{2} \mathrm{~S}$ menggunakan larutan $\mathrm{TiO}$ sulfat (iodometri).

\section{Analisis Geokimia Gas}

Analisis geokimia gas panasbumi menggunakan diagram segitiga $\mathrm{N}_{2} \mathrm{He}-\mathrm{Ar}$ dan $\mathrm{N}_{2}-\mathrm{He}-\mathrm{CO}_{2}$, yang digunakan untuk interpretasi sumber dari gas panasbumi (Powell dan Cumming, 2010). Prinsip kerja dalam penentuan geotermometer adalah menghitung temperatur dari reservoir berdasarkan kadar unsur-unsur pada fluida gas (Arnorsson, 2000). Perhitungan geotermometer gas dilakukan karena sampel gas yang dianalisis mewakili kondisi reservoir. Geotermometer gas digunakan untuk data kimia gas yang berasal dari sumur - sumur produksi dan manifestasi berupa fumarol. Geotermometer gas yang digunakan yaitu $\quad \mathrm{CO}_{2} \quad \mathrm{H}_{2} \mathrm{~S}, \quad \mathrm{H}_{2} ; \quad \mathrm{CO}_{2} / \mathrm{H}_{2}$, $\mathrm{H}_{2} \mathrm{~S} / \mathrm{H}_{2} ;$ dan $\mathrm{CH}_{4} / \mathrm{CO}_{2}$ menurut Arnorsson dan Gunlaugsson. :

$\mathrm{H}_{2} /$ Ar (Giggenbach, 1991),

$\mathrm{T}=70\left[2,5+\log \left(\mathrm{H}_{2} / \mathrm{Ar}\right)\right]$

$\mathrm{H}_{2} \mathrm{~S}$ (Arnorsson dan Gunlaugsson, 1985),

$\mathrm{T}=246,7+44,811 \log \mathrm{mH}_{2} \mathrm{~S}$

$\mathrm{H}_{2}$ (Arnorsson dan Gunlaugsson, 1985),

$\mathrm{T}=277,2+20,99 \log \mathrm{mH}_{2}$ 
$\mathrm{H}_{2} \mathrm{~S} / \mathrm{H}_{2}$ (Arnorsson dan Gunlaugsson, 1985),

$\mathrm{T}=304,1-39,481 \log \mathrm{mH}_{2} \mathrm{~S} / \mathrm{mH}_{2}$

$\mathrm{CO}_{2} / \mathrm{H}_{2}$ (Arnorsson dan Gunlaugsson, 1985),

$\mathrm{T}=341,7-28,571 \log \mathrm{mCO}_{2} / \mathrm{mH}_{2}$

$\mathrm{CO}_{2}$ (Arnorsson dkk., 1998),

$\mathrm{T}=4,724\left(\log \mathrm{mCO}_{2}\right)^{3}-11,068\left(\log \mathrm{mCO}_{2}\right)^{2}+$

$72,012\left(\log \mathrm{mCO}_{2}\right)+121,8$

$\mathrm{H}_{2} \mathrm{~S}$ (Arnorsson dkk., 1998),

$\mathrm{T}=4,811\left(\log \mathrm{mH}_{2} \mathrm{~S}\right)^{2}+66,152\left(\log \mathrm{mH}_{2} \mathrm{~S}\right)+177,6$

$\mathrm{H}_{2}$ (Arnorsson dkk., 1998),

$\mathrm{T}=6,630\left(\log \mathrm{mH}_{2}\right)^{3}+5,836\left(\log \mathrm{mH}_{2}\right)^{2}+56,168$

$\left(\log \mathrm{m} \mathrm{H}_{2}\right)+227,1$

$\mathrm{CO}_{2} / \mathrm{N}_{2}$ (Arnorsson dkk., 1998),
$\mathrm{T}=1,739 \quad\left(\log \mathrm{mCO}_{2} / \mathrm{mN}_{2}+7,599 \quad(\log \right.$ $\left.\mathrm{mCO}_{2} / \mathrm{mN}_{2}\right)^{2}+48,751\left(\log \mathrm{mCO}_{2} / \mathrm{mN}_{2}\right)+173,2$

$\mathrm{H}_{2} \mathrm{~S} / \mathrm{Ar}$ (Arnorsson dkk., 1998),

$\mathrm{T}=4,108\left(\log \mathrm{mH}_{2} \mathrm{~S}+42,256\left(\log \mathrm{mH}_{2} \mathrm{~S} / \mathrm{mAr}\right)+\right.$ 137,6

\section{HASIL}

Peta sebaran manifestasi dan sumur ditampilkan pada Gambar 2, hasil analisis kimia gas ditampilkan pada Tabel 1, untuk selanjutnya diplot pada beberapa diagram segitiga (Gambar 3-5) untuk interpretasi hubungan antar gas terkait beberapa aspek genetik gas tersebut.

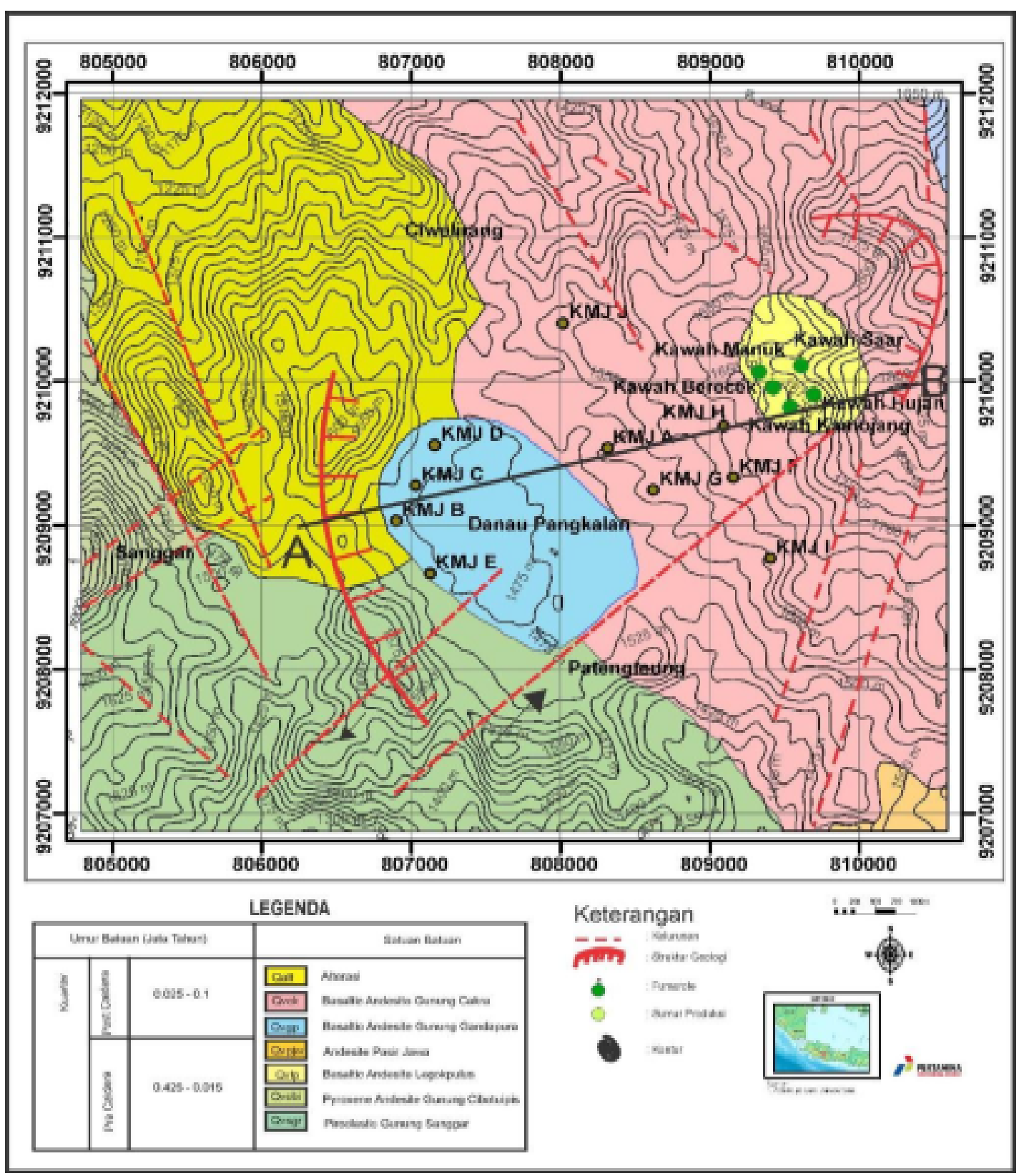

Gambar 2. Peta lokasi sumur dan manifestasi 


\section{Asal-usul Gas Sumur Produksi}

Berdasarkan komposisi unsur gas (Tabel 1), KMJ - I memiliki kadar gas total lebih besar daripada KMJ - B (KMJ - I = 0,69wt.\%, $\mathrm{KMJ}-\mathrm{B}=0,10 \quad$ wt.\%). Hal tersebut diinterpretasikan bahwa pada saat proses separasi gas akibat pendidihan, gas pada KMJ - I mengalami proses separasi gas dalam satu tahap separasi (mengindikasikan gas berasal langsung dari reservoir) dibandingkan data gas pada sumur KMJ - B yang telah melalui lebih dari satu kali separasi gas atau disebut dengan pendidihan yang berkesinambungan. Kondisi ini dibuktikan dari kadar gas total dalam uap yang kecil, yaitu $<2 \mathrm{wt} \% \mathrm{CO}_{2}$. Hidrogen dan sulfur dioksida $\left(\mathrm{SO}_{2}\right)$ bereaksi menghasilkan hidrogen sulfida $\left(\mathrm{H}_{2} \mathrm{~S}\right)$ yang mengakibatkan unsur hidrogen mengalami pengurangan konsentrasi. Akibat pembentukan $\mathrm{H}_{2}$ yang lambat pada saat oksidasi $\mathrm{Fe}_{2}+\mathrm{SO}_{2}$ bereaksi dengan $\mathrm{H}_{2} \mathrm{~S}$ menghasilkan endapan sulfur. Proses oksidasi terhadap $\mathrm{H}_{2} \mathrm{~S}$ menjadi sulfat juga mempengaruhi komposisi gas $\mathrm{H}_{2} \mathrm{~S}$ (Nicholson, 1993) seperti pada persamaan 11.

$$
\mathrm{SO}_{2} \text { (magmatic gas) }+2 \mathrm{H}_{2} \mathrm{~S}=3 \mathrm{~S}+2 \mathrm{H}_{2} \mathrm{O}
$$

Komposisi unsur Amonia $\left(\mathrm{NH}_{3}\right)$ pada KMJ - F lebih besar dari KMJ - I menjelaskan bahwa KMJ - F terletak di zona outflow. Amonia adalah unsur gas yang terlarut dan unsur ini semakin besar ke zona outflow.

Berdasarkan diagram perbandingan komposisi $\mathrm{H}_{2}-\mathrm{H}_{2} \mathrm{~S}-\mathrm{CH}_{4}$, gas-gas pada kesepuluh sumur berada di posisi mendekat ke arah sudut $\mathrm{H}_{2}$, sedangkan sumur $\mathrm{KMJ}$ - A berada pada posisi mendekat ke sudut $\mathrm{CH}_{4}$. Diagram $\mathrm{H}_{2} \mathrm{~S}-\mathrm{CH}_{4}-$ $\mathrm{H}_{2}$ (Gambar 3) menunjukkan bahwa kesepuluh sumur produksi di lapangan Kamojang mengandung fluida yang sudah mengalami mature water dan fluida tidak lagi bereaksi dengan batuan-bbatuan di sekitarnya. Namun, sumur $\mathrm{KMJ}$ - A memiliki nilai $\mathrm{CH}_{4}$ yang lebih tinggi, hal ini mengindikasikan bahwa di sumur KMJ - A, fluida mengalami re-boiling (kondensasi). Penentuan asal gas menggunakan diagram segitiga $\mathrm{N}_{2}-\mathrm{He}-\mathrm{Ar}$ dan diagram segitiga $\mathrm{N}_{2}-\mathrm{Ar}-\mathrm{CO}_{2}$ menurut Powell dan Cumming (2010).

\section{Diagram Segitiga N2-He-Ar}

Penentuan asal gas salah satunya dilakukan dengan menggunakan diagram segitiga $\mathrm{N}_{2}-\mathrm{He}-$ Ar menurut Powell dan Cumming (2010). Diperlukan adanya evaluasi fluida gas untuk mempertegas terutama tentang asal - usul fluida berdasarkan interpretasi diagram trilinier $\mathrm{N}_{2}$-He-Ar. Nicholson (1993) menjelaskan bahwa unsur $\mathrm{N}_{2}$ dapat menjadi indikator pengaruh gas atmosfer atau magmatik. Kondisi ini dapat berasal dari pengaruh magmatik jika rasio $\mathrm{N}_{2} / \mathrm{Ar}$ berada pada nilai $800-2000$. He merupakan indikator karakteristik crustal, sumbernya berasal dari peluruhan batuan yang mengandung Uranium, sedangkan Argon banyak terdapat di gas atmosfer yang dapat terkandung dalam gas panasbumi melalui influx air hujan. Hasil dari plot diagram segitiga $\mathrm{N}_{2}-\mathrm{He}$-Ar yang terlihat pada Gambar 4 masih dapat digunakan walaupun data helium tidak terekam dan disimpulkan bahwa gas panasbumi berasal dari air hujan. Dari diagram 4, terlihat bahwa kesepuluh sampel sumur produksi yang berada di lapangan Kamojang, menunjukkan bahwa fluida panasbumi berasal dari air meteorik yang masuk ke dalam reservoir melalui patahan - patahan yang ada (zona recharge).

Tabel 1. Hasil Analisis Kimia Gas

\begin{tabular}{lcccccccccc}
\hline Parameter & KMJ-A & KMJ-B & KMJ-C & KMJ-D & KMJ-E & KMJ-F & KMJ-G & KMJ-H & KMJ-I & KMJ-J \\
\hline $\mathrm{CO}_{2}$ & 81,77 & 76,04 & 88,1 & 83,49 & 81,41 & 89,12 & 89,86 & 87,18 & 95,01 & 89,58 \\
$\mathrm{H}_{2} \mathrm{~S}$ & 10,96 & 15,13 & 6,64 & 8,6 & 11,69 & 6,52 & 6,57 & 7,75 & 2,395 & 5,64 \\
$\mathrm{NH}_{3}$ & 0,25 & 0,19 & 0,27 & 0,33 & 0,14 & 0,34 & 0,095 & 0,14 & 0,085 & 0,33 \\
$\mathrm{Ar}$ & 0,023 & 0,01 & 0,044 & 0,040 & 0,016 & 0,41 & 0,014 & 0,035 & 0,016 & 0,398 \\
$\mathrm{~N}_{2}$ & 3,4 & 4,3 & 1,9 & 2,0 & 3,6 & 0,7 & 2,146 & 2,4 & 1,735 & 0,8 \\
$\mathrm{CH}_{4}$ & 1,42 & 0,347 & 0,28 & 0,369 & 0,3107 & 0,535 & 0,181 & 0,406 & 0,096 & 0,53 \\
$\mathrm{H}_{2}$ & 2,18 & 3,98 & 2,79 & 5,155 & 2,822 & 2,384 & 1,126 & 2,144 & 0,664 & 2,75 \\
$\%$ berat & 0,19 & 0,10 & 0,20 & 0,18 & 0,19 & 0,26 & 0,44 & 0,23 & 0,69 & 0,28 \\
\hline
\end{tabular}


Tabel 2. Hasil perhitungan Geotermometer $\left(\mathrm{T}\right.$ dalam $\left.{ }^{\circ} \mathrm{C}\right)$

\begin{tabular}{|c|c|c|c|c|c|c|c|c|c|c|}
\hline Geotermometer & KMJ-A & KMJ-B & KMJ-C & KMJ-D & KMJ-E & KMJ-F & KMJ-G & KMJ-H & KMJ-I & KMJ-J \\
\hline $\begin{array}{l}\text { Giggenbach, } \\
1991 \mathrm{H} 2 / \mathrm{Ar}\end{array}$ & 313,9 & 345,8 & 301,3 & 322,6 & 343,3 & 225,3 & 309,2 & 300,3 & 288 & 229,4 \\
\hline A\&G-H2S & 293,2 & 299,5 & 283,5 & 288,5 & 294,5 & 283 & 283,3 & 286,5 & 263,6 & 280,3 \\
\hline A\&G-H2 & 284,3 & 289,7 & 286,5 & 292 & 286,6 & 285 & 278 & 284 & 273 & 286 \\
\hline $\begin{array}{l}\text { A\&G- } \\
\mathrm{H} 2 \mathrm{~S} / \mathrm{H} 2\end{array}$ & 276,4 & 291,8 & 279,7 & 295,3 & 281,2 & 282,1 & 273,8 & 282,1 & 282,1 & 286,8 \\
\hline $\begin{array}{l}\mathrm{A} \& \mathrm{G}- \\
\mathrm{CO} 2 / \mathrm{H} 2\end{array}$ & 296,7 & 298,5 & 296,7 & 295,3 & 281,2 & 282,1 & 273,8 & 282,1 & 282,1 & 286,8 \\
\hline $\mathrm{A}-\mathrm{CO} 2$ & 252,1 & 248,3 & 254,7 & 252,8 & 251,9 & 249,5 & 255,5 & 254,4 & 257,5 & 255,3 \\
\hline $\mathrm{A}-\mathrm{H} 2 \mathrm{~S}$ & 254,3 & 263,3 & 235,2 & 243,6 & 253,7 & 234,7 & 234,9 & 240,2 & 203,4 & 230,0 \\
\hline A - H2 & 249,9 & $\begin{array}{c}264,3 \\
3\end{array}$ & 249,9 & 272,4 & 254,2 & 249,5 & 249,9 & 249,9 & 217,2 & 253,5 \\
\hline $\begin{array}{l}\mathrm{A}- \\
\mathrm{CO} 2 / \mathrm{N} 2\end{array}$ & 180,8 & 178,6 & 192,5 & 190 & 180,2 & 298,2 & 188,8 & 186,5 & 195,6 & 273,9 \\
\hline
\end{tabular}

A\&G = Arnorsson dan Gunlaugsson, 1985; A= Arnorsson dkk., 1998.

Pada sumur KMJ - J dan KMJ - F memiliki nilai Argon yang tertinggi dibanding dengan sumur lainnya. Namun di diagram triangular $\mathrm{He}-\mathrm{N}_{2}-\mathrm{Ar}$ ini, nilai He tidak terdeteksi.

\section{Diagram Segitiga $\mathrm{N}_{2}-\mathrm{Ar}-\mathrm{CO} 2$}

Diagram segitiga $\mathrm{N}_{2}$-Ar-CO2 memiliki fungsi yang sama dengan diagram segitiga $\mathrm{N}_{2}-\mathrm{He}-\mathrm{Ar}$, hanya saja unsur helium diganti dengan $\mathrm{CO}_{2}$. Berdasarkan diagram perbandingan komposisi $\mathrm{N}_{2}-\mathrm{CO}_{2}$ - Ar, gas-gas pada sumur berada diantara Air point (N2/Ar ratio) dan garis yang menghubungkan white island ratio dengan $\mathrm{Ar}$ apex. Semakin dekat ke arah garis maka mengindikasikan bahwa semakin dekat ke arah zona upflow. Selain itu dapat juga mengindikasikan adanya sedikit pengaruh magmatik. Dari diagram $\mathrm{CO}_{2}-\mathrm{N}_{2}-\mathrm{Ar}$ (Gambar 5) menunjukkan bahwa pada sumur $\mathrm{KMJ}$ - F dan KMJ - J memiliki nilai Ar yang tinggi di bandingkan dengan sumur - sumur lainnya. Hal ini dapat diinterpretasi karena tiga kemungkinan:

1. Terjadi kesalahan teknik sampling gas, sehingga menyebabkan nilai Ar tinggi. Argon sendiri merupakan gas udara bebas di atmosfer.

2. Udara masuk lewat air meteorik dan terjadi kontaminasi. Ar mungkin berasal dari leaching batuan.

3. Ar menjadi indikasi dari marginal recharge, bisa jadi sudah ada recharge atau dekat dengan zona recharge.

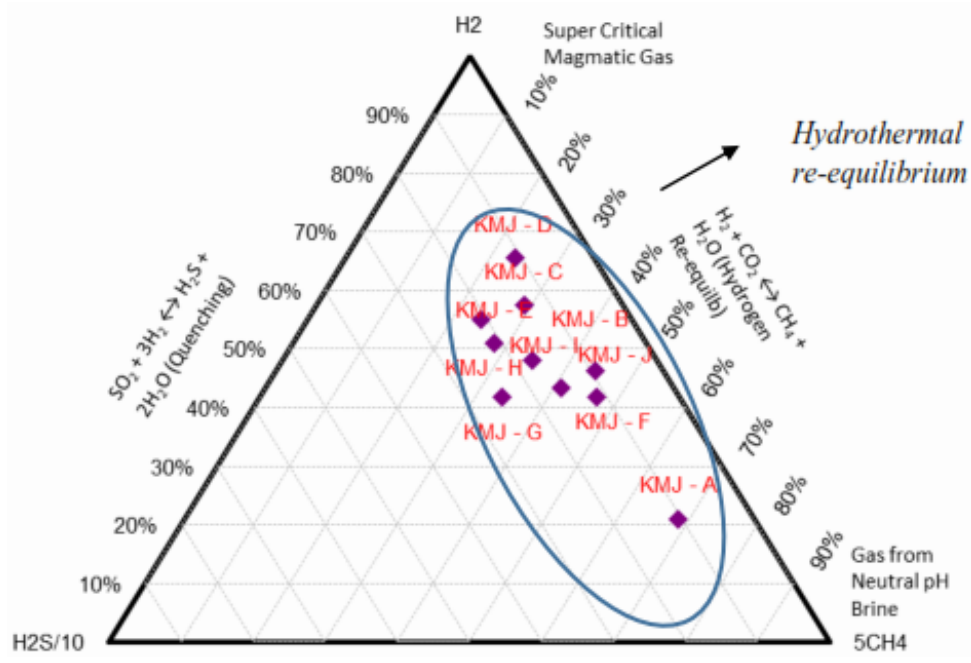

Gambar 3. Diagram segitiga $\mathrm{H}_{2}-\mathrm{H}_{2} \mathrm{~S}-\mathrm{CH}_{4}$ 


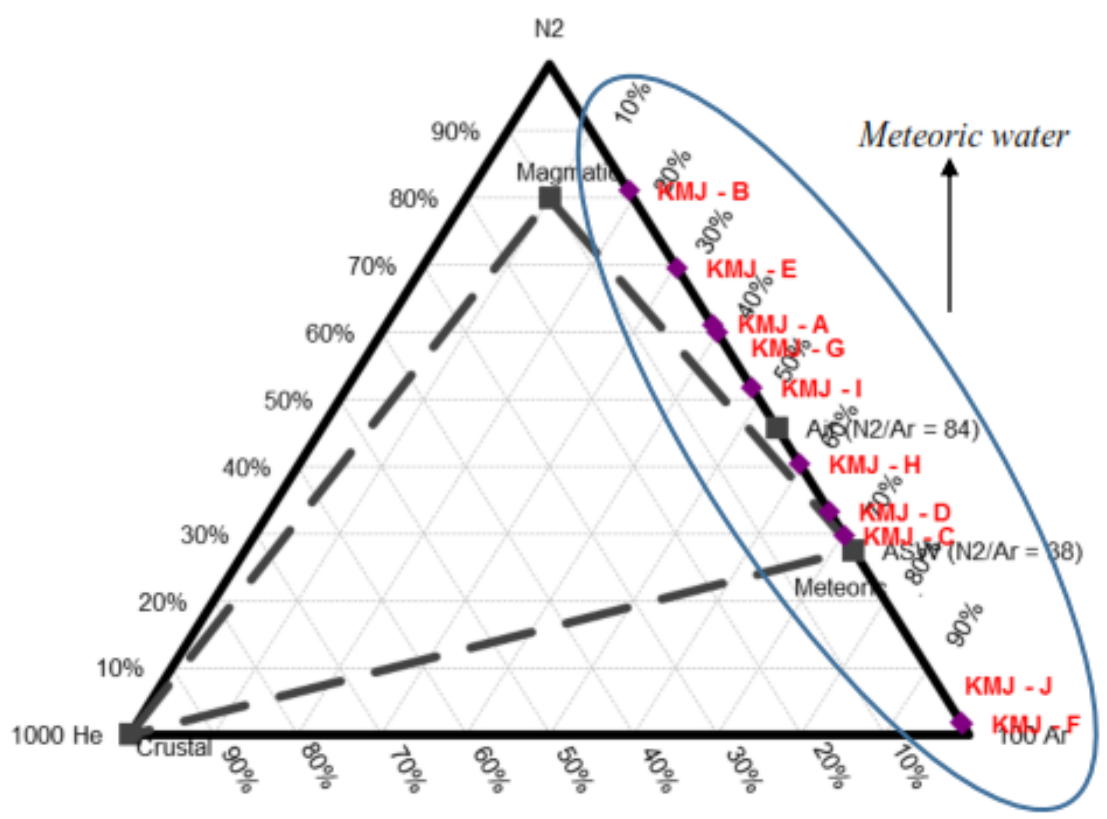

Gambar 4 Diagram segitiga $\mathrm{N}_{2}-\mathrm{He}-\mathrm{Ar}$

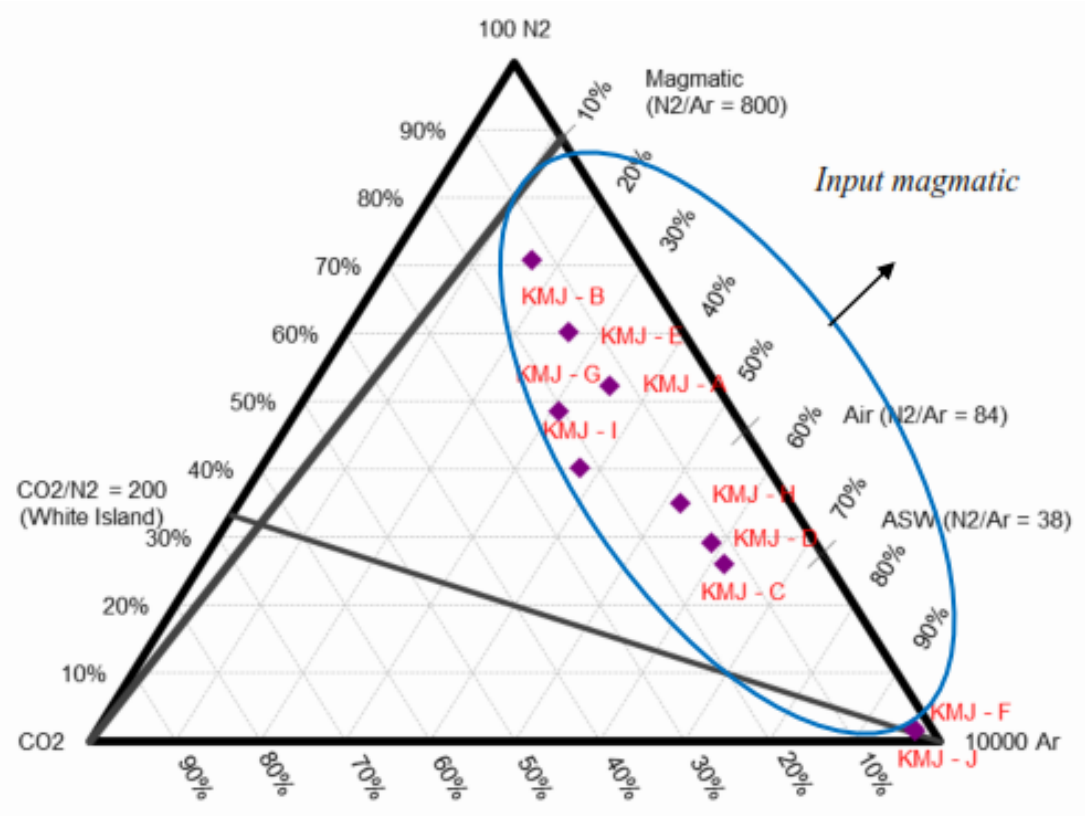

Gambar 5 Diagram segitiga $\mathrm{N}_{2}-\mathrm{CO}_{2}-\mathrm{Ar}$

Pada sumur KMJ - B, terlihat bahwa nilai $\mathrm{N}_{2}$ lebih tinggi dibanding sumur-sumur lainnya. $\mathrm{N}_{2}$ sendiri merupakan unsur dari atmosfer. Pada Gambar 5, KMJ - G lebih mendekati garis gas atmosfer dibandingkan KMJ - I dan diinterpretasikan bahwa KMJ - G lebih mendekati zona upflow dibandingkan KMJ - I dikarenakan KMJ - G memiliki konsentrasi $\mathrm{CO}_{2}$ yang besar $\left(\mathrm{CO}_{2}\right.$ adalah unsur gas utama di sistem panasbumi).

\section{Diagram Segitiga $\mathrm{CO}_{2}-\mathrm{H}_{2} \mathrm{~S}-\mathrm{NH}_{3}$}

Berdasarkan diagram perbandingan komposisi $\mathrm{CO}_{2}-\mathrm{H}_{2} \mathrm{~S}-\mathrm{NH}_{3}$, gas-gas pada sumur berada pada posisi mendekat ke sudut $\mathrm{CO}_{2}$. Dari diagram diatas, terlihat bahwa sumur KMJ - I memiliki nilai $\mathrm{CO}_{2}(95,01 \mathrm{mmol} / \mathrm{kg})$ dan nilai NCG $(0,69 w t \%)$ yang tinggi dibanding sumur - sumur lainnya. $\mathrm{CO}_{2}$ sendiri merupakan less soluble gas dibandingkan dengan $\mathrm{H}_{2} \mathrm{~S}$. Diagram juga mengindikasikan bahwa kesepuluh sumur produksi yang ada di daerah Kamojang bahwa fluida lebih bergerak ke arah zona upflow. Hal ini dilihat dari nilai $\mathrm{CO}_{2}$ yang cukup signifikan. Pada sumur KMJ - F dan KMJ - J menjauhi zona aliran utama, karena nilai $\mathrm{NH}_{3} \mathrm{KMJ}-\mathrm{F}$ yaitu $0,34 \mathrm{mmol} / \mathrm{kg}$ dan $0,33 \mathrm{mmol} / \mathrm{kg}$ untuk $\mathrm{KMJ}-\mathrm{I}$ cukup tinggi. 
Sedangkan pada KMJ - B memiliki nilai H2S $(15,13 \mathrm{mmol} / \mathrm{kg})$ yang tinggi, hal ini mengindikasikan bahwa pada sumur KMJ - B mengalami proses kondensasi. Pada diagram ini, kesepuluh sumur produksi yang ada di lapangan Kamojang tidak menunjukkan sumur - sumur yang ada di tepian (marginal) reservoir.

\section{Temperatur Berdasarkan Geotermometer Gas}

Pengukuran temperatur reservoir didasari atas hasil dari perhitungan beberapa geotermometer gas (Tabel 2), namun tidak seluruh geotermometer gas dapat digunakan dalam menentukan temperatur reservoir. Berdasarkan penjelasan sebelumnya ada beberapa geotermometer yang tidak dipakai (Giggenbach (1991) dalam Altamirano (2006) - CH4/CO2, Arnorsson and Gunnlaugsson (1985) dalam Arnorsson (2000) - $\mathrm{CO}_{2}$, Arnorsson dkk. (1998 dalam Altamirano 2006) $-\mathrm{H}_{2} / \mathrm{Ar}$ yang disebabkan oleh dua hal, yaitu: nilai dari temperatur yang sangat tinggi $\left(>374^{\circ} \mathrm{C}\right)$ dan temperatur terlampau rendah.

Dari tabel hasil perhitungan geotermometer gas (Tabel 2), maka dapat diperkirakan temperatur reservoir berkisar $230-279,7^{\circ} \mathrm{C}$. Sistem panasbumi dengan temperatur tersebut termasuk ke dalam sistem panasbumi bertemperatur tinggi (Hochstein, 1990).

\section{KESIMPULAN}

Sistem panasbumi Kamojang Garut memiliki karakteristik sebagai berikut: diagram segitiga $\mathrm{N}_{2}$-He-Ar, fluida pada sumur $\mathrm{B}, \mathrm{E}, \mathrm{A}, \mathrm{G}$ berasal dari gas magmatik, sedangkan sumur I, H, D, C dari air meteorik. Input fluida gas pada sistem diperkirakan berasal dari gas magmatik. Suhu reservoir di daerah penelitian berkisar antara $230-279,7^{\circ} \mathrm{C}$.

\section{UCAPAN TERIMA KASIH}

Terimakasih yang sebesar-besarnya kepada Pertamina Geothermal Energy Kamojang yang telah menyediakan data kimia gas.

\section{DAFTAR PUSTAKA}

Altamirano, J. I. C., 2006. Sampling and Analyses of Geothermal Steam and Geothermometer Applications in Krafla, Theistareykir, Reykjanes and Svartsengi,
Iceland. Geothermal Training Programme, Iceland

Arnorsson, S., Gunlaugsson, E., 1985. New Gas Geothermometers For Geothermal Exploration - Calibration and Application, Geochimica et Cosmochimica Acta, vol 49, hal. $1307-1325$

Arnorsson, S., Andresdottir, A., Gunnarsson, I., dan Stefánsson, A., 1998. New calibration for the quartz and $\mathrm{Na} / \mathrm{K}$ geothermometers - valid in the range 0 $350^{\circ} \mathrm{C}$ (in Icelandic). Proceedings of the Geoscience Society of Iceland Annual Meeting, April, 42-43.

Arnorsson, S., 2000. Isotopic and Chemical Techniques in Geothermal Exploration, Development and Use: Sampling Methods, Data Handling, Interpretation. International Atomic Energy Agency, Vienna.

D'Amore, F. dan Truesdell, A.H. 1985. Calculation of Geothermal Reservoir Temperatures and Steam Fractions From Gas Compostion; Trans. Geothermal Resources Council, Vol. 9, Part 1, August 1985, hal. 305-310.

D'Amore, F., Panichi, C., 1980, Evaluation of deep temperatures of hydrothermal systems by a new gas geothermometer, Geochimica et Cosmochimica Acta, vol.44, hal. 549 556.

Giggenbach, W. F., dan Glover., R. B., 1992. Tectonic Regime and Major Processes Governing The Chemistry of Water and Gas Discharges From The Rotorua Geothermal Field, New Zealand, Geothermics, Vol 21, 121-140

Giggenbach W. F., dan Goguel, R. L., 1989. Collection and Analysis of Geothermal and Volcanic Water and Gas Discharge, Chemistry Division, Departement of Science and Industrial Research: Selandia Baru.

Giggenbach, W., 1991, Geothermal gas equilibria, Geochimica et Cosmochimica Acta, vol.44, hal. 393-410

Hochstein, M. P., 1990). Classification and assessment of geothermal resources. UNITAR/UNDP Centre for Small Energy Resources, Rome, Italy. hal. 31-59.

Nicholson, K., 1993. Geothermal Fluids: Chemistry and Exploration Techniques 
Springer-Verlag Berlin Heidelberg: Berlin.

Powell, T. dan Cumming, W., 2010.

Spreadsheets For Geothermal Water and GasGeochemistry. Proceedings, Thirty-Fifth Workshop on Geothermal ReservoirEngineering, Stanford University: California. 